JURNAL NUANSA INFORMATIKA

Volume 13 Nomor 1, Januari 2019
p-ISSN : 1858-3911, e-ISSN : 2614-5405

https://journal.uniku.ac.id/index.php/ilkom

\title{
IMPLEMENTASI ALGORITMA FLOYD WARSHALL PADA APLIKASI PENGADUAN MASYARAKAT BERBASIS ANDROID
}

\author{
Regita Novianti ${ }^{1}$, Rio Andriyat Krisdiawan ${ }^{2}$ \\ Fakultas Ilmu Komputer Universitas Kuningan \\ Jalan Tjut Nyak Dhien No. 36 A Cijoho Kuningan Jawa Barat 45513Telepon (0232) 2875097 \\ Regitanovianti15@gmail.com ${ }^{1}$, rioandriyat@uniku.ac.id / rioandriyat@gmail.com ${ }^{2}$
}

Masyarakat menjadi salah satu stake-holder kepolisian dalam kejadian kecelakaan lalu lintas, dimana masyarakat sebagai saksi yang ikut serta membantu aparat dengan melakukan pengaduan. Dalam melakukan pengaduan biasanya masyarakat menggunakan pesan singkat (sms) atau telepon sehingga masyarakat harus memiliki nomor kontak pribadi anggota kepolisian yang bisa dihubungi. Pengelolaan pengaduan harus dikelola dengan baik dan tepat sasaran yaitu antara lain menyediakan sarana pengaduan, menugaskan pelaksana yang berkompeten, menangani pengaduan dan menindaklanjuti pengaduan. Untuk mempermudah masyarakat dalam melakukan pengaduan maka dibutuhkan aplikasi pengaduan untuk mengetahui dan mencari polsek yang akan dihubungi. Aplikasi yang akan dikembangkan berdasarkan penelitian awal yang bertempat di Polres Kabupaten Kuningan. Aplikasi berbasis mobile yang banyak dibutuhkan dalam mencari polsek dan lokasi kejadian lakalantas serta memberikan deskripsi kejadian lakalantas. Aplikasi yang di buat dapat menampilkan lokasi kejadian lakalantas di Kabupaten Kuningan. Dalam menemukan rute terdekat akan ditampilkan berupa maps. Polsek bisa memilih petunjuk arah dari detail pengaduan, kemudian sistem akan menampilkan hasil berupa rute yang ada di maps. Dan di aplikasi ini tersedia layanan untuk mencari lokasi masyarakat dengan menggunkan teknologi GPS. Serta penulis menggunakan algoritma Floyd Warshall untuk menentukan polsek terdekat dan menentukan rute dari lokasi polsek ke lokasi kejadian. Untuk penyimpanan data pada aplikasi ini penulis menggunkan MySQL atau phpMyAdmin sebagai web server dalam menyimpan data kejadian dan data polsek, notifikasi dan laporan yang bersangkutan dengan aplikasi pengaduan. Dan pada pembangunan aplikasi ini berbasis client-server.

Kata Kunci : Algoritma Floyd Warshall, GPS, Kabupaten Kuningan, Mobile, MySQL, Polsek, phpMyAdmin, web server, Masyarakat.

Public complaints are complaints from the public, Government Agencies or other parties verbally or in writing containing information, complaints, dissatisfaction or irregularities in the performance of the National Police that require further handling and settlement. In conducting complaints, the community usually uses short messages (sms) or telephone so that the community must have a personal contact number of the police member who can be contacted. To make it easier for the public to make complaints, a complaint application is needed to find out the policeman to be contacted. Application that will be developed based on preliminary research that took place at Kuningan Police Station. Mobile-based applications that are needed a lot in searching for police and the location of traffic accidents and providing a description of pastoral events. The application that is created only shows the location of the accident in Kuningan Regency. In finding the nearest route, it will be displayed in the form of maps. The police can choose directions from the details of the complaint, then the system will display the results in the form of a route on maps. In this application there is also a service to find out the location of the community by using GPS technology. And the author uses the Floyd Warshall algorithm to determine the nearest police station and determine the route from the location of the police station to the scene. As well as in storing data in this application the author uses MySQL or phpMyAdmin as a web server 
JURNAL NUANSA INFORMATIKA

Volume 13 Nomor 1, Januari 2019
p-ISSN : 1858-3911, e-ISSN : 2614-5405

https://journal.uniku.ac.id/index.php/ilkom

in storing event data and police data, notifications and reports concerned with the complaint application. And in the development of this application is based on clientserver.

Keywords: Floyd Warshall Algorithm, GPS, Kuningan Regency, Mobile, MySQL, Police station, phpMyAdmin, Web Server, Community.

\section{PENDAHULUAN}

Teknologi komunikasi yang berkembang saat ini telah memungkinkan manusia untuk terhubung satu sama lain tanpa dibatasi jarak, ruang, dan waktu, dimana salah satu teknologi komunikasi yang berkembang sangat cepat adalah dengan adanya smartphone. Smartphone merupakan salah satu media komunikasi yang menjadi sorotan karena memiliki kecanggihan dalam berbagai hal serta fungsinya yang dapat digunakan kapan saja dan dimana saja. Smartphone memiliki kemampuan seperti komputer, biasanya memiliki layar yang besar dan sistem operasinya mampu menjalankan tujuan aplikasi-aplikasi yang umum.(Dijey : 2013)

Saat ini hampir setiap individu masyarakat telah memiliki smartphone yang senantiasa dibawa kemana pun dalam beraktifitas artinya teknologi secara tidak langsung sudah dapat diakses oleh hampir seluruh lapisan masyarakat dan menjadi peluang besar dalam pengembangan layanan masyarakat yang lebih luas dan efektif.

Namun melihat dari perkembangan teknologi yang cepat ini belum terlalu sepenuhnya dimanfaatkan oleh pemerintah, salah satu contohnya adalah yang dilakukan oleh lembaga kepolisian dalam bidang pelayanan untuk masyarakat khususnya dalam melayani pengaduan dari masyarakat. Berdasarkan Undang-Undang Nomor 2 tahun 2012 Pasal 1 tentang pengaduan masyarakat yaitu pengaduan dari masyarakat, Instansi Pemerintah atau pihak lain secara lisan atau tertulis mengandung informasi, keluhan, ketidakpuasan atau adanya penyimpangan atas kinerja Polri yang memerlukan penanganan dan penyelesaian lebih lanjut. Maka dari itu, pengelolaan pengaduan harus dikelola dengan baik dan tepat sasaran yaitu antara lain menyediakan sarana pengaduan, menugaskan pelaksana yang berkompeten, menangani pengaduan dan menindaklanjuti pengaduan

Sistem pengaduan masyarakat diharapkan dapat menampung informasi dari masyarakat yang khusus nya ditujukan kepada lembaga kepolisian dalam menangani dan menidaklanjuti pengaduan. Namun demikian, sistem pengaduan masyarakat yang berjalan saat ini pada lembaga kepolisian masih terpaku pada sistem pesan singkat (sms) atau telepon dimana masyarakat harus memiliki nomor kontak pribadi anggota kepolisian yang bisa dihubungi, penggunaan hotline service yang tidak adanya validasi data pelapor menyebabkan banyaknya laporan kejadian lakalantas yang tidak akurat serta kurangnya pemahaman masyarakat dalam melakukan prosedur atau tatacara dalam melakukan pengaduan kepada lembaga kepolisian.

Dengan adanya permasalahan diatas diperlukan suatu sistem dalam bidang pelayanan untuk masyarakat khususnya dalam melakukan pengaduan masyarakat agar lebih mudah dan efektif. Mendasar pada permasalahan diatas sekaligus sebagai upaya membantu menyelesaikan masalah yang ada, maka dalam tugas akhir ini penulis mengambil judul "Implementasi Algoritma Floyd Warshall Pada Aplikasi Pengaduan Masyarakat Berbasis Android (Studi Kasus: Polres Kabupaten Kuningan)".

Berdasarkan latar belakang masalah diatas, maka dapat di identifikasi masalah yang akan dibahas pada penelitian ini yaitu :

1. Sistem pengaduan masyarakat yang berjalan masih terpaku pada sistem pesan singkat (sms) atau telepon sehingga masyarakat harus memiliki nomor kontak pribadi anggota kepolisian yang bisa dihubungi.

2. Penggunaan hotline service yang tidak adanya validasi data pelapor sehingga 
JURNAL NUANSA INFORMATIKA

Volume 13 Nomor 1, Januari 2019

menyebabkan banyaknya laporan kejadian lakalantas yang tidak akurat.

3. Kurangnya pemahaman masyarakat dalam melakukan prosedur atau tatacara dalam melakukan pengaduan kepada lembaga kepolisian, sehingga pelapor harus mencari polsek terdekat dari lokasi kejadian.

Adapun batasan masalah yang melingkupi aplikasi ini adalah sebagai berikut:

1. Aplikasi pengaduan masyarakat ini berbasis client server. dengan platform android untuk client atau masyarakat dan platform web untuk polres kabupaten kuningan.

2. Aplikasi ini dibangun menggunakan bahasa pemrogramman Java dan PHP serta MySQL sebagai DBMS (Database Management System) struktur penyimpanan data.

3. Pemodelan sistem yang akan digunakan dalam aplikasi pengaduan masyarakat ini adalah pemodelan dengan menggunakan UML (Unified Modeling Language).

4. Aplikasi ini hanya untuk pengaduan mengenai kejadian lakalantas dimana masyarakat dapat memberikan informasi dan mengirimkan lokasi kejadian kecelakaan yang terjadi di daerah kabupaten kuningan

5. Algoritma Floyd Warshall digunakan untuk mencari lokasi polsek terdekat dan menentukan rute terdekat dari polsek ke lokasi kejadian lakalantas yang terjadi didaerah kabupaten kuningan.

6. Aplikasi pada polres dapat menerima laporan mengenai kejadian lakalantas yang sudah ditangani oleh polsek terdekat.

7. Aplikasi ini dapat dijalankan pada smartphone yang menggunakan sistem operasi Android versi 4.0 keatas (Jelly Bean) dengan api level minimal 16.

Adapun tujuan dari penelitian ini adalah secara umum untuk:

1. Merancang serta membangun aplikasi berbasis android yang dapat menyediakan layanan pengaduan masyarakat

2. Memudahkan masyarakat dalam melakukan pengaduan khususnya
p-ISSN : 1858-3911, e-ISSN : 2614-5405

https://journal.uniku.ac.id/index.php/ilkom

kejadian lakalantas di kabupaten kuningan.

3. Membuat pengaduan masyarakat yang dapat memperoleh respon lebih cepat dan efektif.

4. Aplikasi yang dapat menghubungkan masyarakat dengan lembaga kepolisian.

Manfaat dari penelitian ini diharapkan masyarakat dapat lebih mudah dalam melakukan pengaduan dan mendapat respon penanganan yang lebih cepat jika melihat atau mengalami kejadian lakalantas yang terjadi di daerah Kabupaten Kuningan.

\section{METODELOGI PENELITIAN}

\subsection{Metodelogi Pengembangan Sistem}

Metode pengembangan perangkat lunak yang digunakan oleh penulis dalam penelitian ini adalah pendekatan Rational Unified Proces (RUP). Rational Unified Process (RUP) merupakan suatu metode rekayasa perangkat lunak yang dikembangkan dengan mengumpulkan berbagai best practises yang terdapat dalam industri pengembangan perangkat lunak. Ciri utama metode ini adalah menggunakan use-case driven dan pendekatan iteratif untuk siklus pengembangan perangkat lunak. Gambar dibawah menunjukkan secara keseluruhan arsitektur yang dimiliki RUP.

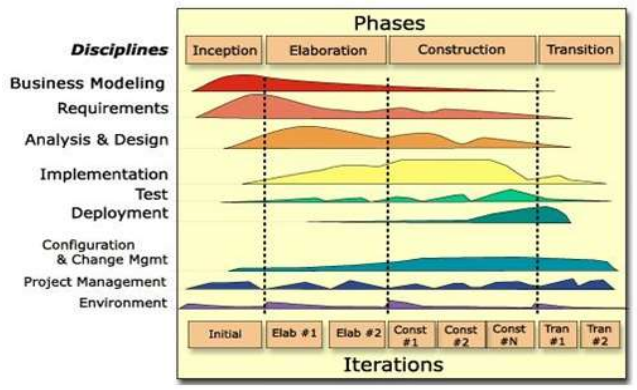

Gambar 1. Rational Unified Process Metode Rational Unified Process memiliki empat tahap dalam pengembangan perangkat lunak yaitu :

1. Permulaan (Inception)

Menentukan Ruang lingkup proyek., membuat 'Business Case', menjawab pertanyaan "apakah yang dikerjakan dapat menciptakan 'good business 
JURNAL NUANSA INFORMATIKA

Volume 13 Nomor 1, Januari 2019

sense sehingga proyek dapat dilanjutkan.

2. Perluasan / Perencanaan (Elaboration)

Menganalisa berbagai persyaratan dan resiko, menetapkan 'base line', merencanakan fase berikutnya yaitu construction.

3. Konstruksi (Construction)

Melakukan sederetan iterasi, pada setiap iterasi akan melibatkan proses berikut: analisa desain, implementasi dan testing.

4. Transisi (Transition)

Membuat apa yang sudah dimodelkan menjadi suatu produk, beta dan performance testing, membuat dokumentasi tambahan seperti; training, user guides dan sales kit, membuat rencana peluncuran produk ke komunitas pengguna.

\subsection{Algoritma}

Algoritma adalah urutan logis langkahlangkah penyeleseian masalah yang disusun secara sistematis. Alur pemikiran dalam menyelesaikan suatu pekerjaan yang dituangkan secara tertulis. Yang ditekankan pertama adalah alur pikiran, sehingga algoritma seseorang dapat juga berbeda dari algoritma orang lain. Sedangkan penekanan kedua adalah tertulis, yang artinya dapat berupa kalimat, gambar, atau tabel tertentu.

Algoritma dapat dituliskan dalam berbagai notasi, misalnya dalam notasi kalimatkalimat deskriptif. Dengan notasi kalimat deskriptif, deskripsi setiap langkah dijelaskan dengan bahasa sehari-hari secara jelas. Setiap langkah biasanya diawali dengan kata kerja seperti 'baca', 'hitung', 'masukan', 'bagi', 'ganti', dan sebagainya. Sedangkan pernyataan bersyarat dinyaakan dengan 'jika', 'maka', dan sebagainya.

\subsubsection{Algoritma Floyd Warshall}

Algoritma Floyd-Warshall adalah salah satu varian dari pemrograman dinamis, yaitu suatu metode yang melakukan pemecahan dengan memandang solusi yang akan diperoleh sebagai suatu keputusan yang saling terkait. Artinya solusi-solusi tersebut dibentuk dari solusi yang berasal dari tahap
p-ISSN : 1858-3911, e-ISSN : 2614-5405

https://journal.uniku.ac.id/index.php/ilkom

sebelumnya dan ada kemungkinan solusi lebih dari satu

Algoritma Floyd Warshall adalah dengan membandingkan semua lintasan yang mungkin terjadi dalam graf untuk setiap pasang simpul dan melakukan pengujian dari setiap kombinasi simpul yang diperoleh. Misalkan $\mathrm{w}_{\mathrm{o}}$ matriks ketetanggaan awal adalah matriks ketetanggan terpendek dengan $\mathrm{W}_{\mathrm{ij}}$ sama dengan path terpendek dari $\mathrm{V}_{\mathrm{i}} \mathrm{ke} \mathrm{V}_{\mathrm{j}}$

Proses penentuan nilai minimum algoritma Floyd warshall dapat dituliskan sebagai berikut:

1. Pada iterasi ke-1, setiap sel matriks dilakukan pengecekan apakah jarak antar dua titik mula mula lebih besar dari penjumlahan antar jarak titik asal ke titik tujuan (titik tujuan=iterasi ke-1) dengan jarak titik asal (titik asal=iterasi ke-1) ke titik tujuan. Dengan kata lain apakah $W[i, j]>W[i, k]+W[k, j]$.

2. Jika iya maka jarak antar dua titik mula mula diganti dengan penjumlahan antar jarak titik asal ke titik tujuan (titik tujuan=iterasi ke-1) dengan jarak titik asal (titik asal=iterasi ke-1) ke titik tujuan $(W[i, k]+W[k, j])$.

3. Jika tidak, maka jarak yang digunakan yaitu jarak antar dua titik mula mula $(W[i, j])$.

4. Proses iterasi dilakukan hingga pada iterasi terakhir (jumlah iterasi=jumlah total titik).

Berikut adalah contoh perhitungan algoritma Floyd warshall untuk menentukan rute terdekat menuju polsek, dimana node I adalah lakalantas dan node $\mathbf{M}$ adalah Polsek Kuningan.

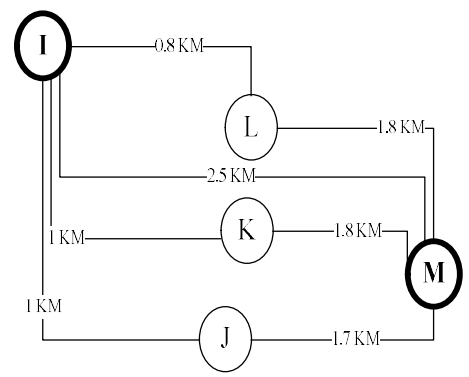

Gambar 2. Graf Sederhana sebagai sampel 
JURNAL NUANSA INFORMATIKA

Volume 13 Nomor 1, Januari 2019

Dari graf tersebut selanjutnya sistem akan melakukan perhitungan dengan Floyd warshall. Berikut ini uraian langkahlangkah algoritma pada kasus tersebut.

1. Langkah pertama dibuatlah matrik untuk perhitungan iterasi dalam pencarian jalur terpendek terhadap setiap node yang dapat dicapai secara langsung. Berikut ini tabel matriks dari table matriks

Tabel 1.Matriks pencarian jalur terpendek

\begin{tabular}{|c|c|c|c|c|c|}
\hline Path & I & $\mathrm{L}$ & $\mathrm{K}$ & $\mathrm{J}$ & $\mathrm{M}$ \\
\hline I & 0 & $\begin{array}{l}0.8 \\
\mathrm{~km}\end{array}$ & $\begin{array}{l}1 \\
\mathrm{~km}\end{array}$ & $\begin{array}{l}1 \\
\mathrm{~km}\end{array}$ & $\begin{array}{l}2.5 \\
\mathrm{~km}\end{array}$ \\
\hline $\mathrm{L}$ & $\begin{array}{l}0.8 \\
\mathrm{~km}\end{array}$ & 0 & $\sim$ & $\sim$ & $\begin{array}{l}1.8 \\
\mathrm{~km}\end{array}$ \\
\hline $\mathrm{K}$ & $1 \mathrm{~km}$ & $\sim$ & 0 & $\sim$ & $\begin{array}{l}1.8 \\
\mathrm{~km}\end{array}$ \\
\hline $\mathrm{J}$ & $1 \mathrm{~km}$ & $\sim$ & $\sim$ & 0 & $\begin{array}{l}1.7 \\
\mathrm{~km}\end{array}$ \\
\hline $\mathrm{M}$ & $\begin{array}{l}2.5 \\
\mathrm{~km}\end{array}$ & $\begin{array}{l}1.8 \\
\mathrm{~km}\end{array}$ & $\begin{array}{l}1.8 \\
\mathrm{~km}\end{array}$ & $\begin{array}{l}1.7 \\
\mathrm{~km}\end{array}$ & 0 \\
\hline
\end{tabular}

2. Langkah ketiga, jika pada iterasi ke satu masih terdapat nilai path yang belum ditemukan, maka dilakukan iterasi selanjutnya. Adapun hasil dari pencarian jalur terpendek pada iterasi ke satu adalah sebagai berikut

Tabel 2. Matriks hasil pencarian jalur terpendek

\begin{tabular}{|l|l|l|l|l|l|}
\hline Path & $\mathrm{I}$ & $\mathrm{L}$ & $\mathrm{K}$ & $\mathrm{J}$ & $\mathrm{M}$ \\
\hline $\mathrm{I}$ & 0 & $\begin{array}{l}0.8 \\
\mathrm{~km}\end{array}$ & $\begin{array}{l}1 \\
\mathrm{~km}\end{array}$ & $\begin{array}{l}1 \\
\mathrm{~km}\end{array}$ & $\begin{array}{l}2.5 \\
\mathrm{~km}\end{array}$ \\
\hline $\mathrm{L}$ & 0.8 & 0 & $\begin{array}{l}1.8 \\
\mathrm{~km}\end{array}$ & $\begin{array}{l}1.8 \\
\mathrm{~km}\end{array}$ & $\begin{array}{l}1.8 \\
\mathrm{~km}\end{array}$ \\
\hline $\mathrm{Km}$ & 1 & 1.8 & 0 & 2 & 1.8 \\
& $\mathrm{~km}$ & $\mathrm{~km}$ & & $\mathrm{~km}$ & $\mathrm{~km}$ \\
\hline $\mathrm{J}$ & 1 & 1.8 & 2 & 0 & 1.7 \\
& $\mathrm{~km}$ & $\mathrm{~km}$ & $\mathrm{~km}$ & & $\mathrm{~km}$ \\
\hline \multirow{3}{*}{$\mathrm{M}$} & 2.5 & 1.8 & 1.8 & 1.7 & 0 \\
& $\mathrm{~km}$ & $\mathrm{~km}$ & $\mathrm{~km}$ & $\mathrm{~km}$ & \\
\hline
\end{tabular}

Berdasarkan perhitungan dari tabel matriks tersebut diperoleh kesimpulan bahwa jalur terpendek untuk menuju ke polsek Kuningan yaitu dari node I (Lakalantas) ke node M (Polsek Kuningan) berjarak 2.5 km.
p-ISSN : 1858-3911, e-ISSN : 2614-5405

https://journal.uniku.ac.id/index.php/ilkom

3. HASIL DAN PEMBAHASAN

3.1 Flowchart Algoritma Floyd Warshall

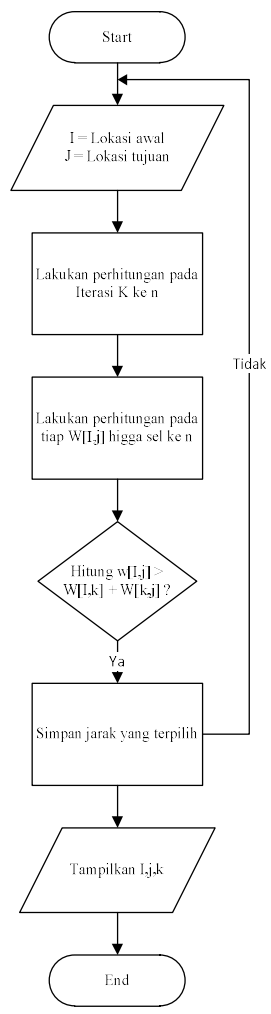

Gambar 3. Flowchart Algoritma Floyd Warshall

\subsection{Perancangan Use Case Diagram}

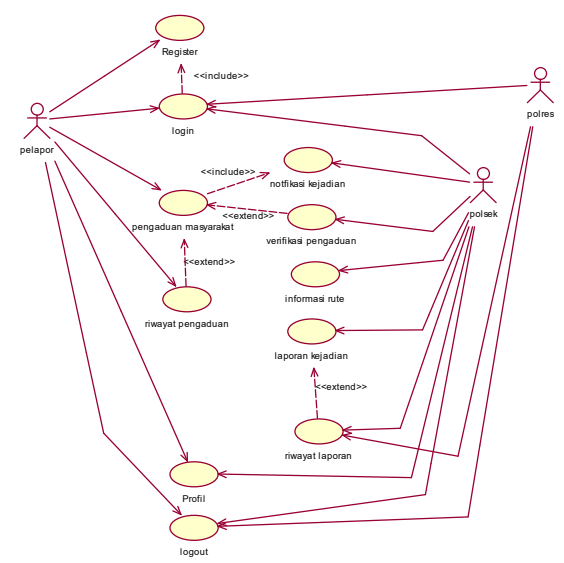

Gambar 4. Use Case Diagram Sistem Adapun deskripsi Use Case Diagram sebagai berikut :

a. Nama Use Case: Pengaduan Masyarakat Tujuan : Melaporkan lakalantas Prioritas : Primary 
JURNAL NUANSA INFORMATIKA

Volume 13 Nomor 1, Januari 2019

$\begin{array}{ll}\text { Actor } & \text { : Pelapor } \\ \text { Precondition } & \text { : Pelapor telah masuk }\end{array}$ pada halaman utama

\begin{tabular}{|c|c|}
\hline Aksi aktor & Reaksi sistem \\
\hline $\begin{array}{l}\text { 1. Memilih } \\
\text { opsi form } \\
\text { pengaduan }\end{array}$ & $\begin{array}{l}\text { 2. Sistem } \\
\text { menampilkan isian } \\
\text { pengaduan. }\end{array}$ \\
\hline $\begin{array}{l}\text { 3. Mengisi } \\
\text { form } \\
\text { pengaduan }\end{array}$ & $\begin{array}{l}\text { 4. Sistem melakukan } \\
\text { validasi terhadap } \\
\text { data } \\
\text { dimasukan yang } \\
\text { database pada } \\
\text { 5. Menampilkan } \\
\text { konfirmasi data isian }\end{array}$ \\
\hline $\begin{array}{l}\text { 6. Melakukan } \\
\text { konfirmasi } \\
\text { data }\end{array}$ & $\begin{array}{l}\text { 7. Sistem memberikan } \\
\text { pemberitahuan } \\
\text { status pengiriman } \\
\text { pengaduan }\end{array}$ \\
\hline Post condition & $\begin{array}{l}\text { Jika pelapor telah } \\
\text { mengisi seluruh form } \\
\text { isian maka pengaduan } \\
\text { dapat dikirim. Jika tidak } \\
\text { maka akan mucul popup } \\
\text { warning untuk mengisi } \\
\text { seluruh form isian. }\end{array}$ \\
\hline
\end{tabular}

b. Nama Use Case: Notifikasi Kejadian Tujuan : Memberikan Informasi Prioritas : Primary

Actor : Polsek

Precondition :Mendapatkan notifikasi pengaduan lakalantas.

\begin{tabular}{|l|l|}
\hline \multicolumn{1}{|c|}{ Aksi aktor } & \multicolumn{1}{|c|}{ Reaksi sistem } \\
\hline $\begin{array}{l}\text { 1. Memilh } \\
\text { opsi } \\
\text { notifikasi }\end{array}$ & $\begin{array}{l}\text { 2. Sistem } \\
\text { menampilkan } \\
\end{array}$ \\
& $\begin{array}{l}\text { laporan pengaduan } \\
\text { sistem mengambil } \\
\text { informasi dari } \\
\text { taging foto yang di } \\
\text { lampirkan pelapor }\end{array}$ \\
\hline Post condition & $\begin{array}{l}\text { sistem akan } \\
\text { menampilkan informasi } \\
\text { pengaduan }\end{array}$ \\
\hline
\end{tabular}

c. Nama Use Case: Informasi Rute

$\begin{array}{ll}\text { Tujuan } & \text { : Menampilkan Rute } \\ \text { Prioritas } & \text { : Primary } \\ \text { Actor } & \text { : Polsek } \\ \text { Precondition } & \text { :Actor }\end{array}$
memverifikasi pengaduan
p-ISSN : 1858-3911, e-ISSN : 2614-5405

https://journal.uniku.ac.id/index.php/ilkom

\begin{tabular}{|c|c|}
\hline Aksi aktor & Reaksi sistem \\
\hline $\begin{array}{l}\text { 1. Memilih opsi } \\
\text { petunjuk arah }\end{array}$ & $\begin{array}{l}\text { 2. Sistem } \\
\text { menampilkan peta }\end{array}$ \\
\hline Post condition & $\begin{array}{lr}\text { sistem } & \text { akan } \\
\text { menampilkan } & \\
\text { informasi } & \text { rute } \\
\text { terdekat dari lokasi } \\
\text { polsek ke lokasi } \\
\text { kejadian lakalantas. }\end{array}$ \\
\hline
\end{tabular}

\subsection{Activity Diagram}

Activity diagram adalah suatu diagram yang menggambarkan konsep aliran data/kontrol, aksi terstruktur serta dirancang dengan baik dalam suatu sistem. Adapun activity diagram pengaduan masyarakat sebagai berikut :

\section{a. Activity Diagram Pengaduan Masyarakat}

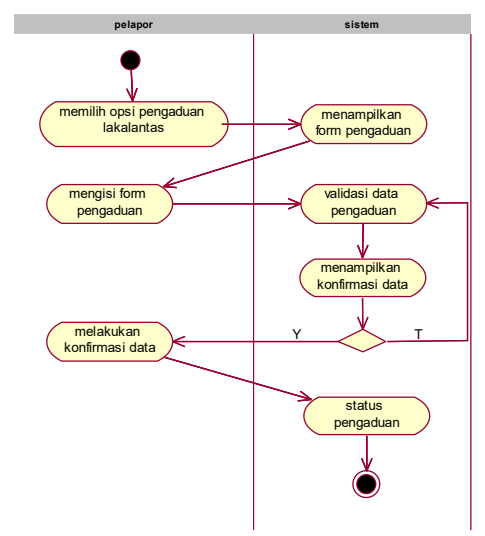

Gambar 5. Activity diagram pengaduan masyarakat

b. Activity Diagram Notifikasi Kejadian

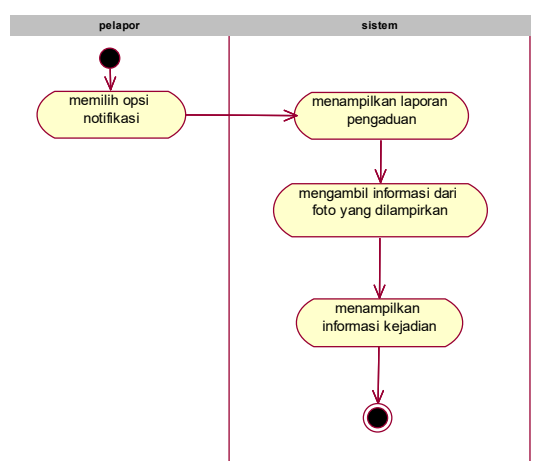

Gambar 6. Activity diagram notifikasi kejadian 
JURNAL NUANSA INFORMATIKA

Volume 13 Nomor 1, Januari 2019

c. Activity Diagram Informasi Rute

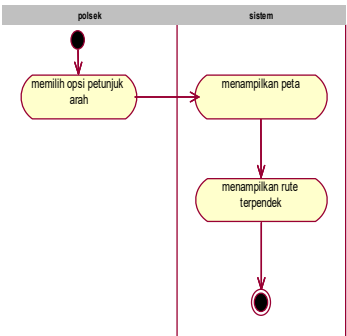

Gambar 7. Activity diagram informasi rute

\subsection{Sequence Diagram}

a. Sequence Diagram Pengaduan Masyarakat

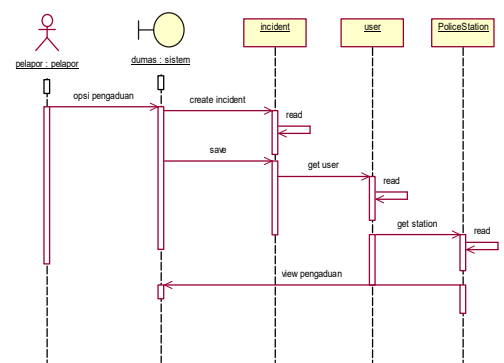

Gambar 8. Sequence diagram pengaduan masyarakat

b. Sequence Diagram Notifikasi Kejadian

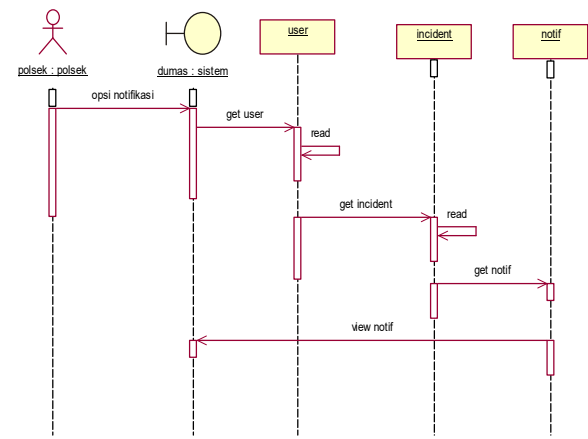

Gambar 9. Sequence diagram notifikasi kejadian

c. Sequence Diagram Informasi Rute

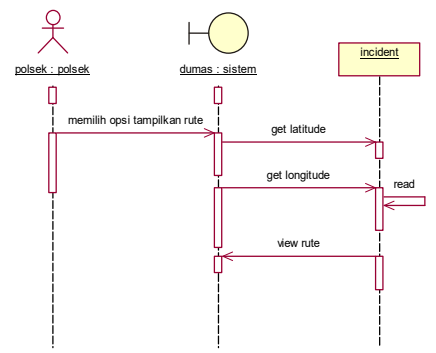

Gambar 10. Sequence diagram informasi rute
p-ISSN : 1858-3911, e-ISSN : 2614-5405

https://journal.uniku.ac.id/index.php/ilkom

\subsection{Class Diagram}

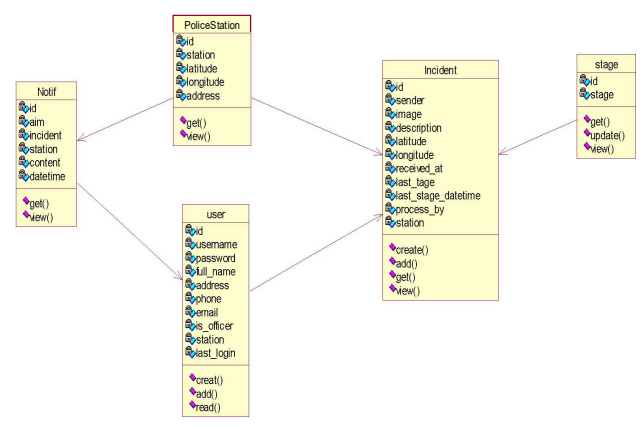

Gambar 11. Class diagram pengaduan masyarakat

\subsection{Construction}

Hasil dari aplikasi yang sudah dirancang dapat dilihat pada tampilan gambar sebagai berikut :

1. Halaman Utama Aplikasi Masyarakat

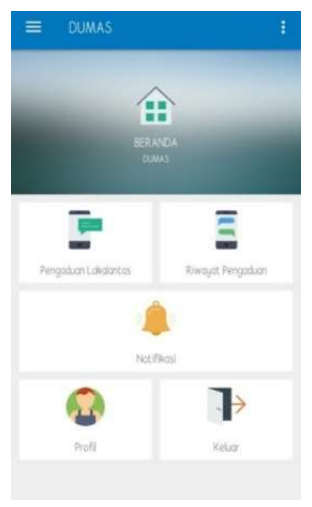

Gambar 12. Halaman utama aplikasi masyarakat

2. Tampilan Menu Pengaduan
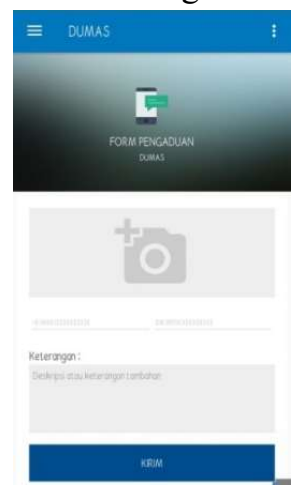

Gambar 13. Tampilan Menu Pengaduan 3. Halaman Utama Aplikasi Polsek 
JURNAL NUANSA INFORMATIKA

Volume 13 Nomor 1, Januari 2019

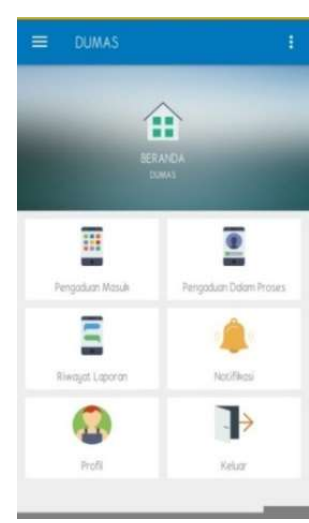

Gambar 14. Halaman Utama Aplikasi Polsek

4. Tampilan Menu Informasi Rute

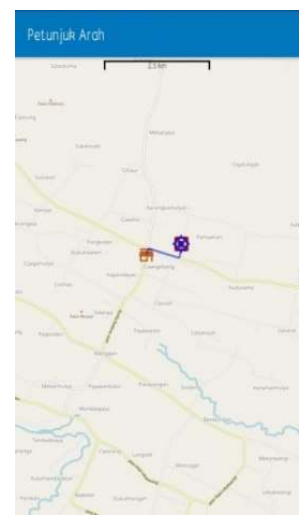

Gambar 15. Informasi Rute

\subsection{Pengujian}

Pengujian bertujuan untuk mecari kesalahan. Pengujian yang baik adalah pengujian yang memiliki kemungkinan besar dalam menemukan kesalahan (Roger S Pressman, 2010:584). Adapun metode pengujian yang dilakukan yaitu sebagai berikut :

\section{Pengujian Black Box}

Pengujian black box bertujuan untuk menguji fungsionalitas aplikasi dan struktur internal kerja.

Tabel 3. Pengujian Aplikasi Masyarakat

\begin{tabular}{|l|l|l|l|}
\hline Kelas Uji & Skenario & $\begin{array}{l}\text { Hasil Yang } \\
\text { diharapkan }\end{array}$ & $\begin{array}{l}\text { Keter } \\
\text { angan }\end{array}$ \\
\hline $\begin{array}{l}\text { Menu } \\
\text { Beranda }\end{array}$ & $\begin{array}{l}\text { Klik menu } \\
\text { beranda }\end{array}$ & $\begin{array}{l}\text { Tampil } \\
\text { halaman } \\
\text { beranda }\end{array}$ & Valid \\
\hline $\begin{array}{l}\text { Menu } \\
\text { Pengaduan } \\
\text { Lakalantas }\end{array}$ & $\begin{array}{l}\text { Klik Menu } \\
\text { form } \\
\text { pengaduan }\end{array}$ & $\begin{array}{l}\text { Tampil } \\
\text { halaman } \\
\text { pengaduan }\end{array}$ & Valid \\
\hline
\end{tabular}

p-ISSN : 1858-3911, e-ISSN : 2614-5405

https://journal.uniku.ac.id/index.php/ilkom

\begin{tabular}{|l|l|l|l|}
\hline $\begin{array}{l}\text { Menu } \\
\text { Riwayat } \\
\text { Pengaduan }\end{array}$ & $\begin{array}{l}\text { Klik menu } \\
\text { riwayat } \\
\text { pengaduan }\end{array}$ & $\begin{array}{l}\text { Tampil } \\
\text { halaman } \\
\text { riwayat } \\
\text { pengaduan }\end{array}$ & Valid \\
\hline $\begin{array}{l}\text { Menu } \\
\text { Notifikasi }\end{array}$ & $\begin{array}{l}\text { Klik menu } \\
\text { notifikasi }\end{array}$ & $\begin{array}{l}\text { Tampil } \\
\text { halaman } \\
\text { notifikasi }\end{array}$ & Valid \\
\hline
\end{tabular}

2. Pengujian White Box

White box testing adalah cara pengujian dengan melihat kedalam modul untuk meneliti kode-kode program yang ada, dan menganalisis apakah ada kesalahan atau tidak. Berikut ini merupakan pengujian kotak putih (white-box testing) dari proses login. Berikut ini merupakan pengujian kotak putih (white-box testing) dari algoritma floyd warshall

Tabel 4 Pengujian White-box Testing

\begin{tabular}{|c|c|}
\hline Node & Source Code \\
\hline 1 & $\begin{array}{l}\text { FW floydWarshall(PoliceStation[] } \\
\text { ps,float[] j) \{ } \\
\text { PoliceStation dummyPoliceStation; } \\
\text { float dummyJarak; }\end{array}$ \\
\hline 2 & for(int $\mathrm{x}=0 ; \mathrm{x}<$ ps.length $-1 ; \mathrm{x}++)\{$ \\
\hline 3 & for(int $y=x+1 ; y<$ ps.length; $y++)\{$ \\
\hline 4 & $\begin{array}{l}\text { if }(\mathrm{j}[\mathrm{x}]>\mathrm{j}[\mathrm{y}])\{ \\
\text { dummyPoliceStation }= \\
\text { policeStation }[\mathrm{x}] ; \text { dummyJarak }= \\
\text { jarak }[\mathrm{x}]\end{array}$ \\
\hline 5 & $\begin{array}{l}\text { policeStation }[\mathrm{x}]= \\
\text { policeStation }[\mathrm{y}] ; \text { jarak }[\mathrm{x}]= \\
\text { jarak }[\mathrm{y}] ; \text { policeStation }[\mathrm{y}]= \\
\text { dummyPoliceStation; jarak }[\mathrm{y}]= \\
\text { dummyJarak; }\} \text { \} } \\
\text { \} FW fW = new } \\
\mathrm{FW}(\text { policeStation }[0], \operatorname{jarak}[0])\end{array}$ \\
\hline 6 & return $\mathrm{fW} ;\}\}$ \\
\hline
\end{tabular}

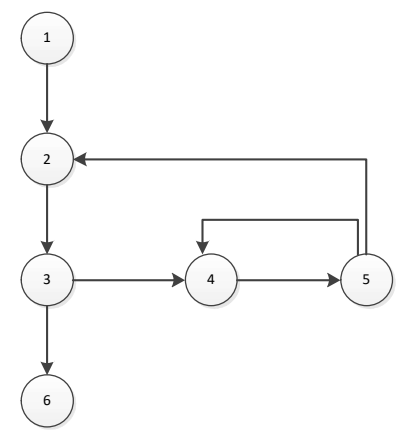

Gambar 17. Flowgraph Notation 
JURNAL NUANSA INFORMATIKA

Volume 13 Nomor 1, Januari 2019

Cylomate Complexcity dari Flowgrap diatas dapat dihitung menggunkan rumus :

$$
\mathrm{V}(\mathrm{G})=(\mathrm{E}-\mathrm{N})+2
$$

Diketahui :

$\mathrm{E}($ Jumlah Edge pada flowgraph $)=7$

$\mathrm{N}$ ( Jumlah Node pada flowgraph $)=6$

Maka V(G) $=(7-6)+2=3$

Dari hasil perhitungan Cylomate Complexcity terdapat jalur yaitu :

Path 1 = 1-2-3-4-5-2

Path $2=1-2-3-4-5-4$

Path $3=1-2-3-6$

\section{Pengujian UAT (User Acceptance Test)} Pengujian $U A T$ yang dilakukan penulis berlangsung di lingkungan user dan melibatkan beberapa pengujian ekstensif oleh sekelompok user.

Untuk mengetahui tanggapan user terhadap aplikasi yang dibangun, maka dilakukan pengujian dengan memberikan 4 pertanyaan kepada 20 user (Pelapor, Polres, Polsek) dimana jawaban dari pertanyaan tersebut terdiri dari tingkatan yang dapat dipilih sebagai berikut:

Tabel 5 Komponen Pilihan Jawaban responden

\begin{tabular}{|c|l|}
\hline A & Sangat : Mudah/Bagus/Sesuai/Jelas \\
\hline B & Mudah/Bagus/Sesuai/Jelas \\
\hline C & Netral \\
\hline D & Cukup : Sulit/Bagus/Sesuai/Jelas \\
\hline E & Sangat : Sulit/Jelek/Tidak Sesuai/Tidak Jelas \\
\hline
\end{tabular}

Tabel 6 Komponen Bobot Nilai responden

\begin{tabular}{|l|c|}
\hline \multicolumn{1}{|c|}{ Jawaban } & Bobot \\
\hline A. Sangat : Mudah/Bagus/Sesuai/Jelas & 5 \\
\hline B. Mudah/Bagus/Sesuai/Jelas & 4 \\
\hline C. Netral & 3 \\
\hline D. Cukup : Sulit/Bagus/Sesuai/Jelas & 2 \\
\hline $\begin{array}{l}\text { E. Sangat : Sulit/Jelek/Tidak } \\
\text { Sesuai/Tidak Jelas }\end{array}$ & 1 \\
\hline
\end{tabular}

Tabel 7 Pertanyaan Quesioner

\begin{tabular}{|c|c|c|c|c|c|c|}
\hline $\begin{array}{l}\mathbf{N} \\
\mathbf{0}\end{array}$ & Pertanyaan & $\mathbf{A}$ & B & C & D & $\mathbf{E}$ \\
\hline 1 & $\begin{array}{l}\text { Apakah Tampilan UI (User } \\
\text { Interface) aplikasi ini menarik? }\end{array}$ & & & & & \\
\hline 2 & $\begin{array}{l}\text { Apakah menu-menu aplikasi ini } \\
\text { mudah dipahami? }\end{array}$ & & & & & \\
\hline 3 & Apakah aplikasi ini userfriendly? & & & & & \\
\hline 4 & $\begin{array}{l}\text { Apakah aplikasi ini membantu } \\
\text { masyarakat dalam melakukan }\end{array}$ & & & & & \\
\hline
\end{tabular}

p-ISSN : 1858-3911, e-ISSN : 2614-5405

https://journal.uniku.ac.id/index.php/ilkom

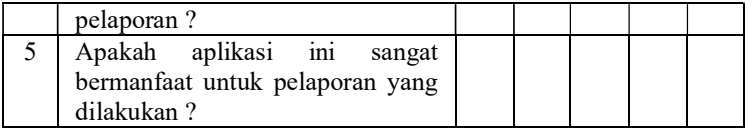

Tabel 8 Data Jawaban Quesioner

\begin{tabular}{|c|c|c|c|c|c|c|c|c|c|c|c|}
\hline \multirow{2}{*}{$\begin{array}{l}\mathbf{N} \\
\mathbf{O}\end{array}$} & \multirow{2}{*}{ Pertanyaan } & \multicolumn{5}{|c|}{ Jawaban } & \multicolumn{5}{|c|}{ Persentase } \\
\hline & & A & B & $\mathrm{C}$ & D & $\mathbf{E}$ & A & B & $\mathrm{C}$ & D & $\mathbf{E}$ \\
\hline 1 & $\begin{array}{l}\text { Apakah } \\
\text { Tampilan } \\
\text { UI (User } \\
\text { Interface) } \\
\text { aplikasi ini } \\
\text { menarik? }\end{array}$ & 15 & 3 & 2 & 1 & & $\begin{array}{l}75 \\
\%\end{array}$ & $\begin{array}{l}15 \\
\%\end{array}$ & $\begin{array}{l}10 \\
\%\end{array}$ & $\begin{array}{c}5 \\
\%\end{array}$ & $\begin{array}{c}0 \\
\%\end{array}$ \\
\hline 2 & $\begin{array}{l}\text { Apakah } \\
\text { menu-menu } \\
\text { aplikasi ini } \\
\text { mudah } \\
\text { dipahami? }\end{array}$ & 10 & 5 & 3 & 2 & 1 & $\begin{array}{l}50 \\
\%\end{array}$ & $\begin{array}{l}25 \\
\%\end{array}$ & $\begin{array}{l}15 \\
\%\end{array}$ & $\begin{array}{l}10 \\
\%\end{array}$ & $\begin{array}{c}5 \\
\%\end{array}$ \\
\hline 3 & $\begin{array}{l}\text { Apakah } \\
\text { aplikasi ini } \\
\text { userfriendly } \\
?\end{array}$ & 10 & 6 & 3 & 1 & & $\begin{array}{l}50 \\
\%\end{array}$ & $\begin{array}{l}30 \\
\%\end{array}$ & $\begin{array}{l}15 \\
\%\end{array}$ & $\begin{array}{c}5 \\
\%\end{array}$ & $\begin{array}{c}0 \\
\%\end{array}$ \\
\hline 4 & $\begin{array}{l}\text { Apakah } \\
\text { aplikasi ini } \\
\text { membantu } \\
\text { masyarakat } \\
\text { dalam } \\
\text { melakukan } \\
\text { pelaporan? }\end{array}$ & 8 & 8 & 2 & 2 & 1 & $\begin{array}{l}40 \\
\%\end{array}$ & $\begin{array}{l}40 \\
\%\end{array}$ & $\begin{array}{l}10 \\
\%\end{array}$ & $\begin{array}{l}10 \\
\%\end{array}$ & $\begin{array}{c}5 \\
\%\end{array}$ \\
\hline 5 & $\begin{array}{l}\text { Apakah } \\
\text { aplikasi ini } \\
\text { sangat } \\
\text { bermanfaat } \\
\text { untuk } \\
\text { pelaporan } \\
\text { yang } \\
\text { dilakukan? }\end{array}$ & 10 & 3 & 3 & 2 & 2 & $\begin{array}{l}50 \\
\%\end{array}$ & $\begin{array}{l}15 \\
\%\end{array}$ & $\begin{array}{l}15 \\
\%\end{array}$ & $\begin{array}{l}10 \\
\%\end{array}$ & $\begin{array}{l}10 \\
\%\end{array}$ \\
\hline
\end{tabular}

Data yang didapat di atas diolah dengan cara mengalikan setiap poin jawaban dengan bobot yang sudah ditentukan sesuai dengan tabel bobot nilai jawaban.

Tabel 9 Data Kuesioner Setelah Diolah

\begin{tabular}{|c|c|c|c|c|c|c|c|c|c|}
\hline \multirow{2}{*}{$\begin{array}{l}\mathbf{N} \\
\mathbf{O}\end{array}$} & \multirow{2}{*}{ Pertanyaan } & \multicolumn{5}{|c|}{ Nilai } & \multirow[t]{2}{*}{ jml } & \multirow[t]{2}{*}{ NR } & \multirow[t]{2}{*}{$\begin{array}{c}\text { NR } \\
\%\end{array}$} \\
\hline & & 5 & 4 & 3 & 2 & 1 & & & \\
\hline 1 & $\begin{array}{l}\text { Apakah } \\
\text { Tampilan UI } \\
\text { (User Interface) } \\
\text { aplikasi ini } \\
\text { menarik? }\end{array}$ & 75 & 12 & 6 & 2 & 0 & 95 & 4,75 & 95 \\
\hline 2 & $\begin{array}{l}\text { Apakah menu- } \\
\text { menu aplikasi ini } \\
\text { mudah dipahami } \\
\text { ? }\end{array}$ & 50 & 20 & 9 & 4 & 1 & 84 & 4,2 & 84 \\
\hline 3 & $\begin{array}{l}\text { Apakah aplikasi } \\
\text { ini userfriendly? }\end{array}$ & 50 & 24 & 9 & 2 & 0 & 85 & 4,25 & 85 \\
\hline 4 & $\begin{array}{l}\text { Apakah aplikasi } \\
\text { ini membantu } \\
\text { masyarakat } \\
\text { dalam } \\
\text { melakukan } \\
\text { pelaporan? }\end{array}$ & 40 & 32 & 6 & 4 & 1 & 83 & 4,15 & 83 \\
\hline 5 & $\begin{array}{l}\text { Apakah aplikasi } \\
\text { ini sangat } \\
\text { bermanfaat } \\
\text { untuk pelaporan } \\
\text { yang dilakukan? }\end{array}$ & 50 & 12 & 9 & 4 & 2 & 77 & 3,85 & 77 \\
\hline
\end{tabular}

Ket : 
JURNAL NUANSA INFORMATIKA

Volume 13 Nomor 1, Januari 2019

$N R=$ Nilai Rata-rata (Jumlah $/$ Responden)

$N R \%=$ Persentase $(N R /$ Point Tertinggi $x$

100)

Dari data diatas dapat disimpulkan bahwa aplikasi tersebut Tampilan UI (User Interface)yang menarik, menu-menu pada aplikasi mudah dipahami, userfriendly, dan dapat membantu masyarakat dan kepolisian dalam melakukan dan menangani pelaporan.

\section{KESIMPULAN}

Berdasarkan hasil implementasai dan pengujian, maka kesimpulan dari penelitian yaitu sebagai berikut :

1. Aplikasi Pengaduan Masyarakat dapat membantu dan memudahkan masyarakat dalam melaporkan kejadian lakalantas yang terjadi di wilayah Kabupaten Kuningan.

2. Dengan adanya aplikasi ini polisi dapat mendapatkan informasi yang akurat apabila mendapatkan pengaduan atau laporan dari masyarakat, karena aplikasi ini dapat memberikan informasi pelapor berserta kejadian lakalantas yang ada di Kabupaten Kuningan.

3. Impelementasi Algoritma Floyd Warshall dapat menemukan polsek terdekat serta menampilkan rute terpendek untuk menuju ke lokasi kejadian.

\section{SARAN}

Dalam Pembuatan Aplikasi Pengaduan Masyarakat ini masih banyak hal yang dapat dikembangkan diantaranya :

1. Perlu ditingkatkannya sistem keamanan seperti melakukan perubahan atau update password secara berkala.

2. Aplikasi Aplikasi Pengaduan Masyarakat ini dapat dikembangkan lebih lanjut lagi tidak hanya untuk melaporkan kejadian lakantas tetapi bisa mencakup kejadian kriminalitas kamtibnas dsb, sehingga aplikasi ini dapat lebih memberikan kemudahan kepada masyarakat dalam melakukan pelaporan.

\section{DAFTAR PUSTAKA}

A.S Rosa dan Salahuddin M,2011. Modul Pemebelajaran Rekayasa Perangkat
p-ISSN : 1858-3911, e-ISSN : 2614-5405

https://journal.uniku.ac.id/index.php/ilkom

Lunak ( Terstruktur dan Berorientasi Objek), Modula, Bandung.

Dijey Pratiwi Barakati,2013,Dampak Penggunaan Smartphone Dalam Pembelajaran Bahasa Inggris. Jurnal www.ejournal.unsrat.ac.id (diakses tanggal 05 Maret 2018 jam 18.30 WIB)

Fanani, Lutffi; J, Eriq M Adams; Wicaksono, Satrio A., 2012, Rancang Bangun Aplikasi Web Pencarian Rute Terpendek Antar Gedung di Kampus Menggunakan Algoritma Floydwarshall, Jurnal Basic Science And Techonology, 1(3),7-11,2012 ISSN : 2089-8185, Malang.

Galih, Elda Candra, and Rio Andriyat Krisdiawan. "IMPLEMENTASI ALGORITMA DIJKSTRA PADA APLIKASI WISATA KUNINGAN BERBASIS ANDROID." NUANSA INFORMATIKA 12.1 (2018).

Jogiyanto, 2010. Analisis dan Desain Sistem Informasi, Edisi IV, Andi, Yogykarta

Munir, R. (2009). Matematika Diskrit. Bandung : Informatika Bandung.

Nazaruddin Safaat H, 2011, Android (Pemrogramman Aplikasi Mobile Smartphone dan Tablet PC berbasis Android). Informatika. Bandung.

Nazruddin, Safaat H. Pemrograman Aplikasi Mobile Smartphone Dan Tablet PC Berbasis Android. Bandung: Informatika,2012.

Peraturan presiden no.76 tahun 2013 tentang pengelolaan Pengaduan Pelayanan Publik

Said iqbal,(2015), Perancangan Simulasi Jalur Terpendek Kota Wisata Medan Menggunakan Algoritma Floyd Warshall. Program Studi Teknik Informatika STIMIK Budi Darma Medan.

Undang-Undang Nomor 2 tahun 2012 tentang pengaduan masyarakat www.polri.go.id

Y. Rudi Kriswanto dkk (2014), Penentuan Jarak terpendek Rute Transmusi dengan Algoritma Floyd Washall. Seminar Nasional Teknologi Informasi \& Komunikas Terapan 2014(SEMANTIK 2014). 